\title{
TANNASE PRODUCTION BY PENICILLIUM ATRAMENTOSUM KM UNDER SSF AND ITS APPLICATIONS IN WINE CLARIFICATION AND TEA CREAM SOLUBILIZATION
}

\author{
Manjit K. Selwal*1, Anita Yadav', Krishan K. Selwal' ${ }^{2}$, N.K. Aggarwal ${ }^{3}$, Ranjan Gupta ${ }^{4}$, S. K. Gautam ${ }^{1}$
}

${ }^{1}$ Department of Biotechnology, Kurukshetra University, Kurukshetra-136119, Haryana, India; ${ }^{2}$ Dairy Microbiology Division, National Dairy Research Institute, Karnal-132001, Haryana, India; ${ }^{3}$ Department of Microbiology, Kurukshetra University, Kurukshetra-136119, Haryana, India; ${ }^{4}$ Department of Biochemistry, Kurukshetra University, Kurukshetra-136119, Haryana, India.

Submitted: June 26, 2010; Approved: November 04, 2010.

\begin{abstract}
Tannin acyl hydrolase commonly known as tannase is an industrially important enzyme having a wide range of applications, so there is always a scope for novel tannase with better characteristics. A newly isolated tannase-yielding fungal strain identified as Penicillium atramentosum KM was used for tannase production under solid-state fermentation (SSF) using different agro residues like amla (Phyllanthus emblica), ber (Zyzyphus mauritiana), jamun (Syzygium cumini), Jamoa (Eugenia cuspidate) and keekar (Acacia nilotica) leaves. Among these substrates, maximal extracellular tannase production i.e. $170.75 \mathrm{U} / \mathrm{gds}$ and 165.56 U/gds was obtained with jamun and keekar leaves respectively at $28^{\circ} \mathrm{C}$ after $96 \mathrm{~h}$. A substrate to distilled water ratio of 1:2(w/v) was found to be the best for tannase production. Supplementation of sodium nitrate $\left(\mathrm{NaNO}_{3}\right)$ as nitrogen source had enhanced tannase production both in jamun and keekar leaves. Applications of the enzyme were studied in wine clarification and tea cream solubilization. It resulted in $38.05 \%$ reduction of tannic acid content in case of jamun wine, $43.59 \%$ reduction in case of grape wine and $74 \%$ reduction in the tea extract after $3 \mathrm{~h}$ at $35^{\circ} \mathrm{C}$.
\end{abstract}

Key words: Tannin acyl hydrolase, Agro residues, Penicillium atramentosum KM, Jamun leaves, SSF.

\section{INTRODUCTION}

Tannin acyl hydrolase (EC 3.1.1.20), commonly called tannase is a hydrolytic enzyme that catalyzes the hydrolysis of ester bonds in hydrolysable tannins such as tannic acid, thereby releasing glucose and gallic acid $(3,19)$. Tannins are naturally occurring water-soluble polyphenols of varying molecular weight depending on the bonds possessed with proteins and polysaccharides. They occur in many edible fruits and vegetables and are often considered nutritionally undesirable because they form complexes with protein, starch and digestive enzymes and cause a reduction in nutritional value of food. Tannase is extensively used in food, beverage and medical industries. In the food industry, it is used in the manufacture of instant tea, as a clarifying agent for haze reduction in wine and bear, in reduction of astringency of fruit juices, and in reducing 
anti-nutritional effects of tannins in animal feed. In the medical industry, it is used in the production of gallic acid, a substrate for the chemical synthesis of trimethoprim, propyl gallate, dyes and inks etc. $(13,14)$. The enzyme is also used in the pretreatment of animal feed additives, to clean-up highly polluting tannin from the effluent of leather industry, pharmaceutical and chemical industries $(2,19)$. Tannases are either membranebound or extracellular, inducible enzyme produced by plants, filamentous fungi, bacteria, and yeast. A number of reports given by different workers showed the use of liquid surface, submerged $(\mathrm{SmF})$ or solid state fermentation (SSF) for the production of tannase. The submerged fermentation is mostly preferred as the sterilization and process-control methods are easier in this method (19). But this technique is not only expensive but also energy intensive, hence, SSF is the alternative method, since obtained levels of tannase are higher on solid substrates. SSF mainly utilizes the agro-industrial residues as its substrates which are not only economical but also easily available. The selection of a suitable substrate for SSF process depends on several factors mainly related with cost, availability, and the homogeneous nature of the substrates. Two types of SSF systems involve (i) cultivation on a natural material and (ii) cultivation on an inert support impregnated with a liquid medium. The first system uses natural materials are usually agricultural products or agroindustrial sources, which serve both as support and a nutrient source. The solid support of the second system, which can also be of natural origin, serves only as an anchor point for the organisms. The filamentous fungi of the Aspergillus genus have been widely used for tannase production $(5,22,30)$. Although Penicillium sp. grows well in tan liquors and is known to produce tannase, however, little information is available on the isolation and production of tannase obtained from this source. There are only few reports on tannase production by Penicillium sp. under SmF conditions $(8,28)$. To the best of our knowledge, Van de Lagemaat and Pyle (35) reported the cultivation of Penicillium glabrum by solid state fermentation on polyurethane foam cubes, which served only as an inert support for the organism, impregnated with a liquid medium containing tannic acid as the main carbon source. They developed a mathematical growth model for the batch solid-state fermentation process for fungal tannase production. So, there is a prior report on tannase production by Penicillium sp under SSF. In our study, we are reporting tannase production by Penicillium atramentosum KM under SSF using cheap and locally available agro residues like jamun and keekar leaves which are an alternative to tannic acid, a costly substrate, and its applications in wine phenolic reduction and tannin removal in solid tea cream.

\section{MATERIALS AND METHODS}

\section{Raw Materials and tannin estimation}

Amla (Phyllanthus emblica), ber (Zyzyphus mauritiana), jamun (Syzygium cumini), jamoa (Eugenia cuspidate) and keekar (Acacia nilotica) leaves were collected from local orchard. These leaves were first dried at $60^{\circ} \mathrm{C}$ in an oven and then finely ground to powdered form in a grinder mixer. The powder was stored in a dry place at room temperature and used as source of crude tannins in SSF. The tannin content was estimated by using the protein precipitation method (15). Dried leaves were ground to fine powder in $70 \%$ methanol and kept overnight at $4^{\circ} \mathrm{C}$. One milliliter of the extract was taken out in a test tube and $3 \mathrm{ml}$ of $\mathrm{BSA}$ solution was added. The reaction mixture was kept for 15 minutes at room temperature. Then, the mixture was centrifuged (5000 x g, $10 \mathrm{~min})$, and the precipitate was dissolved in $3 \mathrm{ml}$ of SDS-triethanolamine solution. Absorbance was measured at $530 \mathrm{~nm}$ after addition of $1 \mathrm{ml}$ of $\mathrm{FeCl} 3$ reagent.

\section{Chemicals}

Tannic acid, bovine serum albumin, sodium dodecyl sulphate was purchased from Sigma Chemical Co. (St. Louis, MO, USA). All other chemicals used were of the analytical 
grade available commercially from Hi-Media Pvt. Ltd. (Mumbai).

\section{Microorganism and inoculum preparation}

The fungal strain used in present investigation was isolated from the tannery effluent using the routine mycological procedures and screened for tannase enzyme production using tannase screening medium comprising $0.5 \%$ tannic acid as the substrate through enrichment technique. The isolated fungal strain was identified as Penicillium atramentosum KM. The fungus has been identified by Prof. Ashok Aggarwal, Mycologist, Department of Botany on the basis of morphological characteristics. Furthermore, to confirm the identity of the isolate, the genetic characterization was performed with ITS4 and ITS5 primers that specifically identify Penicillium by amplifying 600-bp fragment (26). The genus-level and the species-specific specificity of the fungal strain were tested using primer sets ITS4 and ITS5 and PgrisF1-1, PatraR1. A product of approx. 685 bp was amplified by PCR from the tested fungal strain. The qualitative assay of tannase enzyme activity was carried out by culturing the microorganism on the Czapeck's Dox agar plates containing tannic acid $(0.3 \% \mathrm{w} / \mathrm{v})$. The clear hydrolyzing zone around the colonies indicated the tannase activity. The fungal culture was maintained on Czapeck Dox agar slants at $4{ }^{\circ} \mathrm{C}$. For preparation of inoculum, $10 \mathrm{ml}$ of sterilized distilled water supplemented with $0.1 \%$ Tween- 80 was added to 1 -week old fully sporulated agar slant culture.

\section{Effect of substrates on tannase production}

Various solid substrates such as jamun, keekar, amla, ber and jamoa were examined for the tannase production. The mature leaves of each substrate were dried at $60^{\circ} \mathrm{C}$, finely powdered in a grinder mixer and used in SSF. Powdered leaves $(10 \mathrm{~g})$ of each substrate were taken in $250 \mathrm{ml}$ Erlenmeyer flask and 1:2 (w/v) solid substrates: distilled water ratio was maintained. The distilled water was supplemented with $0.1 \%$ $\mathrm{NaNO}_{3}$ (sodium nitrate) in jamun leaves and $0.2 \% \mathrm{NaNO}_{3}$ in
Keekar leaves for tannase production. These contents were autoclaved at $121.5^{\circ} \mathrm{C}$ for 20 minutes. After cooling the flasks to room temperature, the contents were inoculated with $0.1 \mathrm{ml}$ of fungal spore inoculum $\left(3 \times 10^{7}\right.$ spores $\left./ \mathrm{ml}\right)$. The flasks were then incubated at $28^{\circ} \mathrm{C}$ for $96 \mathrm{~h}$ under stationary conditions.

\section{Enzyme Extraction}

The enzyme from each flask was extracted with $0.2 \mathrm{M}$ acetate buffer; $\mathrm{pH} 5.5$ (50 $\mathrm{ml}$ for $10 \mathrm{~g}$ of substrate) (22). Then, these flasks were kept on the rotary shaker at $150 \mathrm{rev} / \mathrm{min}$ for one hour. The contents were squeezed through a wet muslin cloth. The enzyme extract was centrifuged at $10,000 \mathrm{~g}$ for 20 min at $4{ }^{\circ} \mathrm{C}$ and the clear supernatant was used as crude enzyme.

\section{Enzyme assay}

Tannase activity was estimated by the colorimetric method (24). The reaction mixture contained $0.3 \mathrm{ml}$ of substrate tannic acid $(0.5 \% \mathrm{w} / \mathrm{v}$ in $0.2 \mathrm{M}$ sodium acetate buffer, $\mathrm{pH} 5.5$ ) and $0.1 \mathrm{ml}$ of enzyme. This reaction mixture was incubated at $30 \mathrm{oC}$ for one hour. The enzymatic reaction was terminated by addition of $3 \mathrm{ml}$ of BSA solution $(1 \mathrm{mg} / \mathrm{ml})$ which also precipitated the residual tannic acid. A control was prepared side by side using heat denatured enzyme. The tubes were then centrifuged $(5,000 \mathrm{x} \mathrm{g}, 10 \mathrm{~min})$ and the precipitate was dissolved in $3 \mathrm{ml}$ SDS-triethanolamine $(1 \% \mathrm{w} / \mathrm{v}$, SDS in $5 \% \mathrm{v} / \mathrm{v}$, Triethanolamine) solution. One $\mathrm{ml}$ of $\mathrm{FeCl}_{3}$ reagent $\left(0.01 \mathrm{M} \mathrm{FeCl}_{3}\right.$ in $\left.0.01 \mathrm{~N} \mathrm{HCl}\right)$ was added to the tube and was kept for $15 \mathrm{~min}$ at room temperature for stabilization of the color. Absorbance was read at $530 \mathrm{~nm}$ against the blank (i.e., without tannic acid). The specific extinction co-efficient of tannic acid at $530 \mathrm{~nm}$ was found to be 0.577 (24).

Using this co-efficient, one unit of tannase activity is defined as the amount of enzyme required to hydrolyze $1 \mathrm{mM}$ of substrate (tannic acid) in 1 min under assay conditions.

\section{Optimization of process parameters for SSF}

Various physico-chemical process parameters required for 
maximum tannase production by Penicillium atramentosum KM under SSF were determined for substrate (amla, ber, jamoa, jamun and keekar), incubation temperature $\left(20-40^{\circ} \mathrm{C}\right)$, $\mathrm{pH}(5.0$ - 7.0), incubation time $(24-120 \mathrm{~h})$, moisture level (1:1-1:5), supplementation of carbon sources (dextrose, glucose, lactose, mannitol, sucrose) at $0.2 \% \mathrm{w} / \mathrm{v}$, supplementation of nitrogen sources (ammonium chloride, ammonium nitrate, ammonium sulphate, sodium nitrate, potassium nitrate) at $0.2 \% \mathrm{w} / \mathrm{v}$ and supplementation of different concentration of sodium nitrate (0- 0.5\%). All experiments were carried out in triplicate and the mean values were reported with standard deviation.

\section{Application of tannase in wine phenolic reduction}

The colloidal suspension $(10 \mathrm{ml})$ of jamun and grape wine was taken in two beakers respectively and $0.1 \mathrm{ml}$ of ammonium sulphate $(60-80 \%)$ precipitated tannase enzyme was added to it. Then, the mixture was incubated at $35^{\circ} \mathrm{C}$ under stationary conditions for different time intervals and the tannin content was estimated at different time intervals before and after the enzymatic treatment.

\section{Application of tannase in solid tea cream solubilization}

Aqueous extract obtained from black tea contain primary polyphenolic compounds and complexes of polyphenolic compounds and caffeine which are readily soluble in hot water at temperatures above $60^{\circ} \mathrm{C}$. However, when the extract is cooled to room temperature and below, these substances are only partially soluble in the water of the extract. Thus, the cloudiness occurs in the cooled extracts. These solids are also described as turbidity or tea cream (20). This solid tea cream results in haze formation (1). The treatment of tea extract preferably the black tea extracts by the use of enzyme to produce water soluble tea or tea powder of improved astringency and color without turbidity is a great demand in the world (34). The raw tea material used here was collected from the Tea Estates, Sikkim; India. The tea extract was prepared by adding $25 \mathrm{~g}$ of raw tea into $200 \mathrm{ml}$ of boiling distilled water and allowed to stand for $20 \mathrm{~min}$ and filtered through Whatman filter paper No. 1. The filtrate i.e. tea extract was cooled and stored at $4^{\circ} \mathrm{C}$ for $10 \mathrm{~h}$. The solid cream was taken off and suspended in $100 \mathrm{ml}$ distilled water and mixed well. Then, 0.5 $\mathrm{ml}$ of ammonium sulphate $(60-80 \%)$ precipitated tannase enzyme was added to this colloidal tea solution $(6 \mathrm{ml})$ and allowed to stand at $35^{\circ} \mathrm{C}$ for different time periods. The tannic acid content was determined in the sample before and after tannase treatment by protein precipitation method (15).

\section{RESULTS AND DISCUSSION}

The selection of a substrate for a large-scale enzyme production by fermentation depends on its easy availability, cost and production efficiency. Several low cost agro residues were used for production of tannase by Penicillium atramentosum KM through solid state fermentation (SSF) and the best supporter of tannase production were selected. Various parameters were optimized to obtain maximum tannase production (Table 1). In the present investigation, we are reporting for the first time the use of jamun and keekar leaves as solid substrates for the production of tannase by Penicillium atramentosum KM. There are no reports of tannase production through SSF by Penicillium sp. Only a few reports of tannase production Penicillium sp. under Smf are available in literature $(8,28)$.

\section{Effect of the substrate used on tannase production}

The tannin content of each substrate was determined using the protein precipitation method (15). Jamun leaves (135.01 $\mathrm{U} / \mathrm{g}$ ) and Keekar leaves (143.74 U/g) were found to be the best supporter for maximal tannase production (Table 2). This may be due to presence of all soluble nutrients required by fungi in jamun leaves and keekar leaves. In our earlier study also, we reported highest tannase production by Aspergillus fumigatus MA using jamun leaves under SSF (22). It was also observed 
that high tannase activity is not related to high tannin content (22), as high activity of tannase was observed in jamun and jamoa leaves which were found to have lower tannin contents as compared to amla and keekar leaves (Table 2). This may be due to the fact that tannic acid at higher concentration produces complexes with membrane protein of the organism and inhibits the growth and enzyme production (6).

Table 1. Optimum conditions for maximum tannase production by Penicillium atramentosum KM under SSF

\begin{tabular}{|c|c|c|c|}
\hline S. No. & Parameters & SSF Range & Optimum \\
\hline 1 & Incubation period $(\mathrm{h})$ & $24-120$ & 96 \\
\hline 2 & Substrate Used & $\begin{array}{l}\text { Jamoa, Jamun, Amla, } \\
\text { Keekar, Ber }\end{array}$ & Jamun, Keekar \\
\hline 3 & Initial pH & $5-7.0$ & 6.5 \\
\hline 4 & Temperature $\left({ }^{\circ} \mathrm{C}\right)$ & $20-37$ & 28 \\
\hline 5 & $\begin{array}{l}\text { Selection of Moistening agent } \\
\text { a) Modified Czapeck Dox medium } \\
\left(\mathrm{NaNO}_{3}-0.25 \%, \mathrm{KH}_{2} \mathrm{PO}_{4}-0.1 \% \text {, }\right. \\
\left.\mathrm{MgSO}_{4} .7 \mathrm{H}_{2} \mathrm{O}-0.05 \%, \mathrm{KCl}-0.05 \%\right) \text {, } \\
\text { b) } \mathrm{Tap}^{-0} \text { water }\left(\mathrm{Cl}^{-} 0.08 \% ; \mathrm{Ca}^{++} 0.5 \% \text {; }\right. \\
\left.\mathrm{Mg}^{++} 0.5 \% \text {; } \mathrm{HCO}_{3}^{-} 0.4 \%\right), \\
\text { c) Distilled water }\end{array}$ & $\mathrm{a}, \mathrm{b}, \mathrm{c}$ & $\mathrm{c}$ \\
\hline 6 & Substrate : Distilled water ratio & & \\
\hline 7 & $\begin{array}{l}\text { Supplementation: } \\
\text { Carbon sources }(0.2 \%) \\
\text { Nitrogen sources }(0.2 \%)\end{array}$ & $1: 1-1: 5$ & $\begin{array}{c}1: 2 \\
-\end{array}$ \\
\hline 8 & Tannase activity $\left(\mathrm{U} \mathrm{g}^{-1}\right)$ & & $\begin{array}{c}\text { Sodium nitrate } \\
(0.1 \% \text { in Jamun }) \\
(0.2 \% \text { in Keekar }) \\
170.75,165.56\end{array}$ \\
\hline
\end{tabular}

Table 2. Tannin content and tannase activity in different substrates used for SSF

\begin{tabular}{clcc}
\hline S. No. & \multicolumn{1}{c}{ Substrate Used } & $\begin{array}{c}\text { Tannin content } \\
\text { (mg/g dry leaves) }\end{array}$ & $\begin{array}{c}\text { Tannase } \\
\text { Activity } \\
\text { (U/g) }\end{array}$ \\
\hline 1 & Keekar leaves (Acacia nilotica) & 40.19 & 143.74 \\
2 & Jamun leaves (Syzigium cumini) & 35.2 & 135.01 \\
3 & Jamoa leaves (Eugenia cuspidate) & 37.9 & 73.74 \\
4 & Amla leaves (Phyllanthus emblica) & 45.5 & 5.63 \\
5 & Ber leaves (Zyzyphus mauritiana) & 6.7 & 12.63 \\
\hline
\end{tabular}

\section{Effect of incubation time on tannase production}

The maximal tannase production by Penicillium atramentosum $\mathrm{KM}$ was obtained after $96 \mathrm{~h}$ of incubation i.e. $152.06 \mathrm{U} / \mathrm{g}$ in case of jamun leaves and $149.78 \mathrm{U} / \mathrm{g}$ in case of keekar leaves. After that, the enzyme production started decreasing (Fig. 1). This may be due to the accumulation of the end product, gallic acid which hampers tannase production or may be due to appearance of toxic metabolites during fermentation. In our previous study on tannase production by Aspergillus fumigatus MA, we have reported maximum tannase production in $96 \mathrm{~h}$ (22). Similar to our results, Lekha and Lonsane (19) and Sabu et al. (30) also reported maximum 
extracellular tannase production by A. niger in 96 h. Rodriguez et al. (28) reported maximal tannase production after $48 \mathrm{~h}$ by Aspergillus oryzae while, Chatterjee et al. (11) reported maximum extra-cellular production in $120 \mathrm{~h}$ by $R$. oryzae. Banerjee et al. (6) found maximum production of extracellular tannase by A. aculaetus after $72 \mathrm{~h}$.

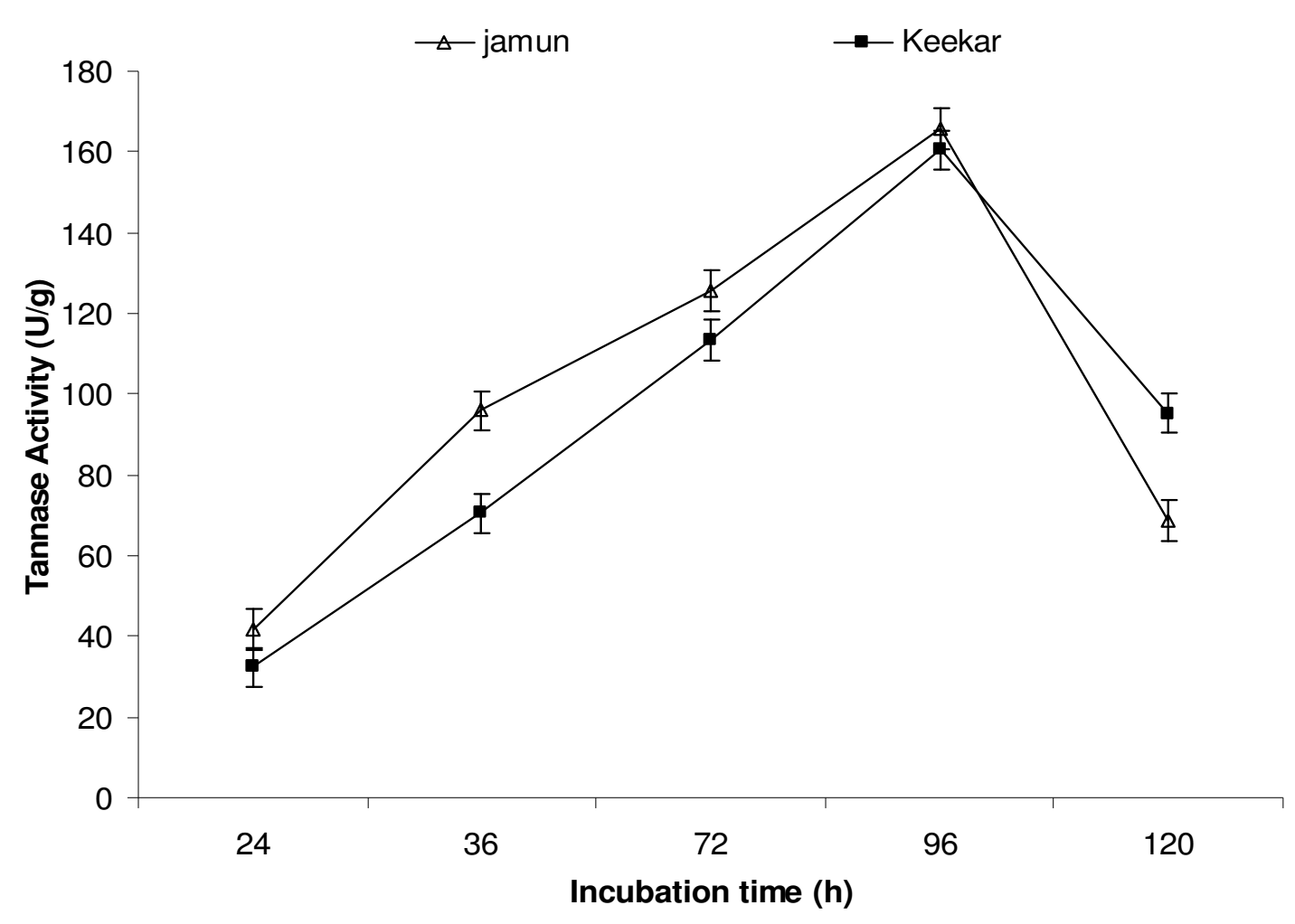

Figure 1. Effect of incubation time on tannase production by Penicillium atramentosum KM.

(Growth conditions: $10 \mathrm{~g}$ jamun/keekar leaves as substrates ( $\mathrm{pH} 5.5$ ) incubated at $25^{\circ} \mathrm{C}$ for $72 \mathrm{~h}, 1: 1$ substrate: moisture agent.)

\section{Effect of incubation temperature on tannase production}

The SSF was carried out for $96 \mathrm{~h}$ at different temperatures i.e. $\left(20-40^{\circ} \mathrm{C}\right)$. The maximum enzyme production i.e. 155.87 $\mathrm{U} / \mathrm{g}$ in jamun leaves and $154.02 \mathrm{U} / \mathrm{g}$ in keekar leaves was observed at $28^{\circ} \mathrm{C}$ (Fig. 2). Above this temperature, there was a decrease in enzyme production which may be due to the fact that with increase in temperature, sporulation is induced that hampers the mycelial growth in fungus. Similar to our results, Anwar et al. (4) also reported maximal tannase production at $28^{\circ} \mathrm{C}$ by $A$. niger. Different workers have reported different optimal temperature for tannase production. A number of workers have reported an optimum temperature around $30^{\circ} \mathrm{C}$ in various fungi $(9,30,5,6,33)$. In our previous report, we reported maximal tannase production by Aspergillus fumigatus MA at an optimal temperature of $25^{\circ} \mathrm{C}$ (22), while, Kasieczka et al. (17) reported optimum temperature of $16^{\circ} \mathrm{C}$ for the maximum tannase production by Verticillium sp. P9. Sabu et al. (31) reported maximal tannase production at $33^{\circ} \mathrm{C}$ under SSF conditions by Lactobacillus sp. ASRS1. 


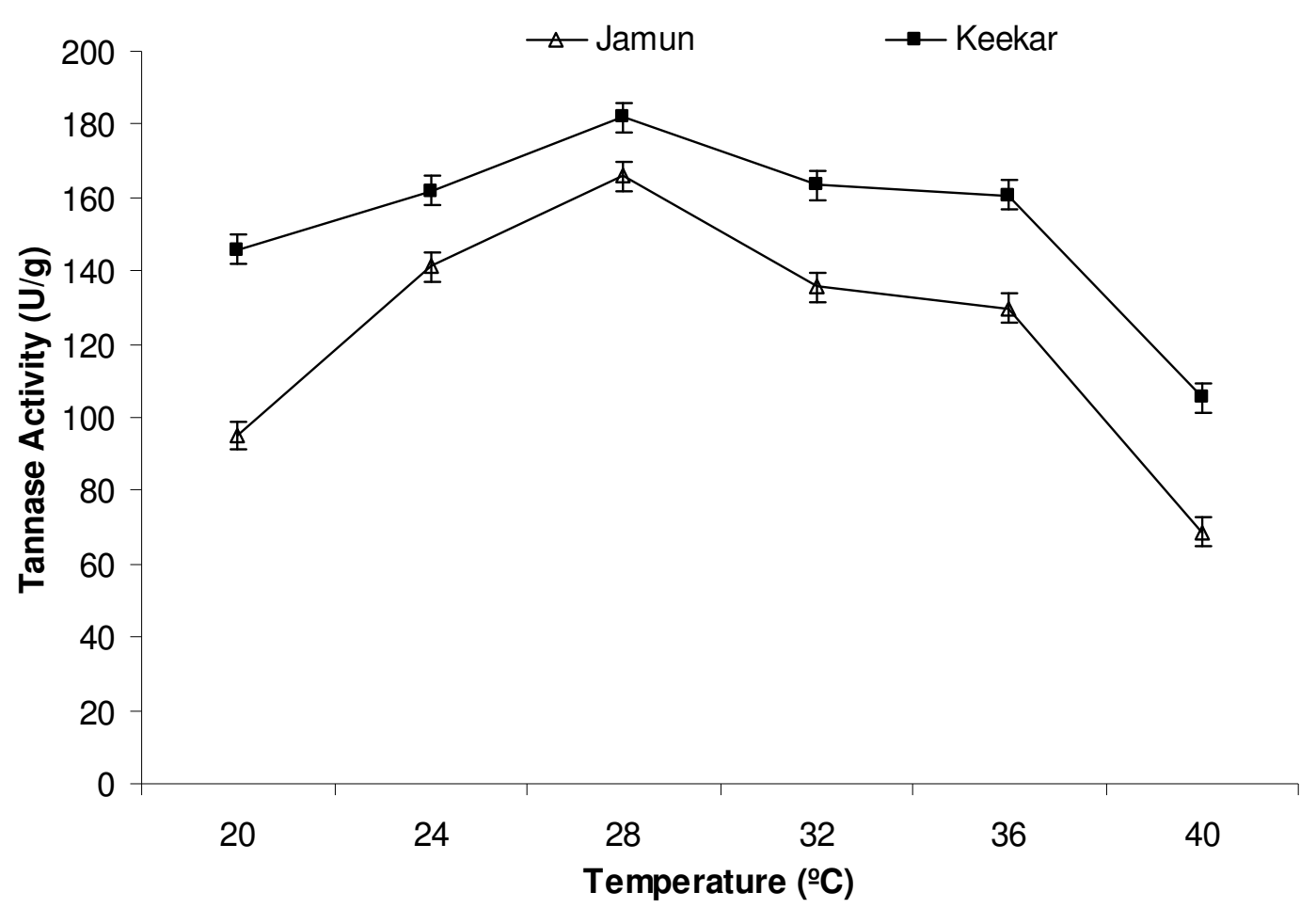

Figure 2. Effect of temperature on tannase production by Penicillium atramentosum KM. (Growth conditions: 10g jamun/keekar leaves as substrates ( $\mathrm{pH} 5.5$ ) incubated for $96 \mathrm{~h}, 1: 1$ substrate:moisture agent.)

\section{Effect of pH on tannase production}

The SSF was carried out for $96 \mathrm{~h}$ at various $\mathrm{pH}$ ranging from 5.0 to 7.0. The optimum $\mathrm{pH}$ was found to be 6.5 for maximum tannase production i.e. $157.21 \mathrm{U} / \mathrm{g}$ with Jamun leaves and $156.12 \mathrm{U} / \mathrm{g}$ with keekar leaves. With increase in $\mathrm{pH}$ of moistening agent, the enzyme production was decreased which may be due to the fact that tannase is acidic glycoprotein having an isoelectric point at about $\mathrm{pH} 4.0$ (25). The acidic environment favors the transport of metal ions into the cells required for metabolic reactions of the organism (19). Similar to our observations, the optimum $\mathrm{pH}$ for tannase production was found to vary from 4.5 to 6.5 in different fungi $(7,14,22$, $25,28,33)$ and bacteria $(18,23,31)$.

\section{Effect of moistening agents}

Different moistening agents such as mineral salt solution
$\left(\mathrm{NaNO}_{3}-0.25 \%, \mathrm{KH}_{2} \mathrm{PO}_{4}-0.1 \%, \mathrm{MgSO}_{4} .7 \mathrm{H}_{2} \mathrm{O}-0.05 \%, \mathrm{KCl}\right.$ $-0.05 \%)$, tap water $\left(\mathrm{Cl}^{-} 0.08 \% ; \mathrm{Ca}^{++} 0.5 \% ; \mathrm{Mg}^{++} 0.5 \% ; \mathrm{HCO}_{3}^{-}\right.$ $0.4 \%$ ) and distilled water were examined for enzyme production under SSF. Distilled water was observed to be the best moisturizing agent for tannase production by Penicillium atramentosum KM yielding $157.82 \mathrm{U} / \mathrm{g}$ in jamun leaves and $156.98 \mathrm{U} / \mathrm{g}$ in keekar leaves. To determine the effect of moisture level, the substrate was moistened using distilled water in different ratios (w/v) starting from 1:1, 1:2, $1: 3,1: 4$ and 1:5. A ratio of $1: 2$ was found to be the best for enzyme production i.e. $160.36 \mathrm{U} / \mathrm{g}$ with jamun and $160.08 \mathrm{U} / \mathrm{g}$ with keekar leaves (Fig. 3). The higher production at 1:2 (substrate: moisture level) might be due to low water activity as required by fungi. Above this the enzyme production was found to decrease. This may be due to the poor oxygen supply with increase in moisture level, thereby, resulting in lesser 
biomass and enzyme production (22). Filamentous fungi are known to grow at water deficient substrates like bark of trees, dry leaves etc. The ability of the organism to produce such a high yield of enzyme with distilled water without addition of any mineral salt in SSF could lead to substantial reduction in overall cost of enzyme production.

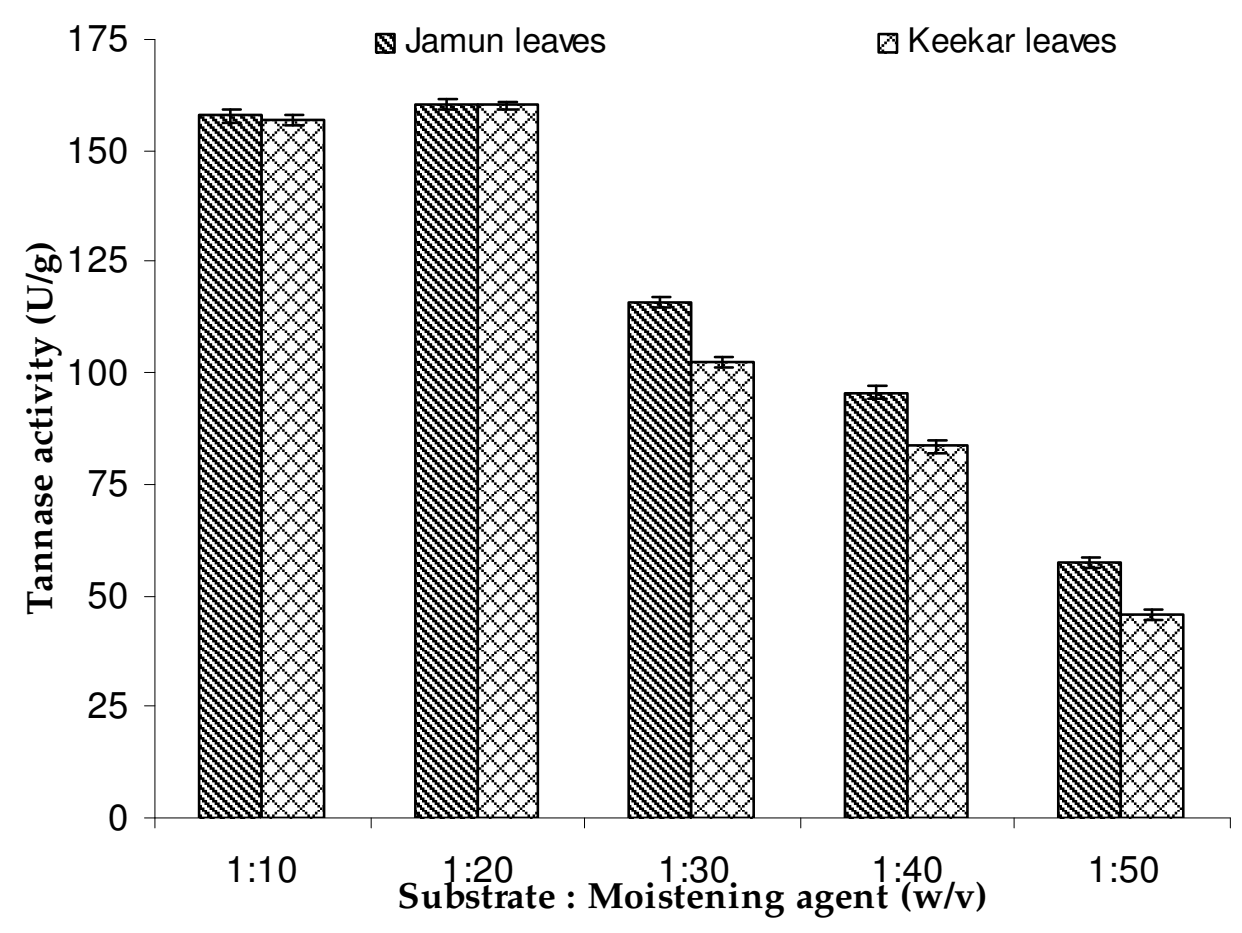

Figure 3. Effect of moisture level on tannase production by Penicillium atramentosum KM

(Growth conditions: $10 \mathrm{~g}$ jamun/keekar leaves as substrates ( $\mathrm{pH} 6.5$ ) incubated at $28^{\circ} \mathrm{C}$ for $72 \mathrm{~h}$.)

\section{Effect of carbon sources on tannase production}

The effect of different carbon sources $(0.2 \% \mathrm{w} / \mathrm{v})$ on the production of tannase was evaluated (Fig. 4). All the carbon sources did not show any stimulatory effect on enzyme production. In our study, jamun and keekar leaves were used as sole carbon sources and inducers of tannase production. This may be due to the fact that additional carbon source created an osmotic stress to depress enzyme synthesis and both the agro residues are already rich enough to supply the nutrients especially the carbon sources required for fungal growth and tannase production. Available reports on the role of carbon sources on the tannase production are contradictory. Sabu et al.
(30) reported the stimulation of tannase production by Aspergillus niger ATCC 16620, when the medium was supplemented with $1 \%(\mathrm{w} / \mathrm{v})$ glycerol using tamarind seed powder (TSP) while in palm kernel cake (PKC), all the additional carbon sources were found inhibitory to the tannase production. Sabu et al. (31) reported that tannase production was inhibited by additional carbon sources in PKC, WB and $\mathrm{CH}$ while maltose at $1.0 \%$ concentration enhanced the tannase production in TSP from Lactobacillus sp. ASR-S1. Bradoo et al. (9) observed that a concentration of $0.2 \%$ glucose favored both growth and tannase production, whereas, a higher concentration of glucose created an osmotic stress to depress 
enzyme synthesis in A. japonicus. Banerjee and Pati, (6) observed Glucose at $0.1 \%(\mathrm{w} / \mathrm{v})$ concentration was most effective for tannase production and beyond that concentration it was inhibitory on tannase production by Aureobasidium pullulans DBS 66 in the medium supplemented with tannic acid. The addition of $2.0 \%$ glucose in the submerged cultures of Aspergillus niger Aa-20 resulted in strong catabolite repression (2). Mondal et al. (23) and Mondal and Pati (24) observed that the addition of low concentrations of glucose, lactose and sucrose $(0.1 \%)$ were not repressive, but at high concentrations $(0.3$ and $0.5 \%)$, these carbon sources repressed tannase production in B. licheniformis.

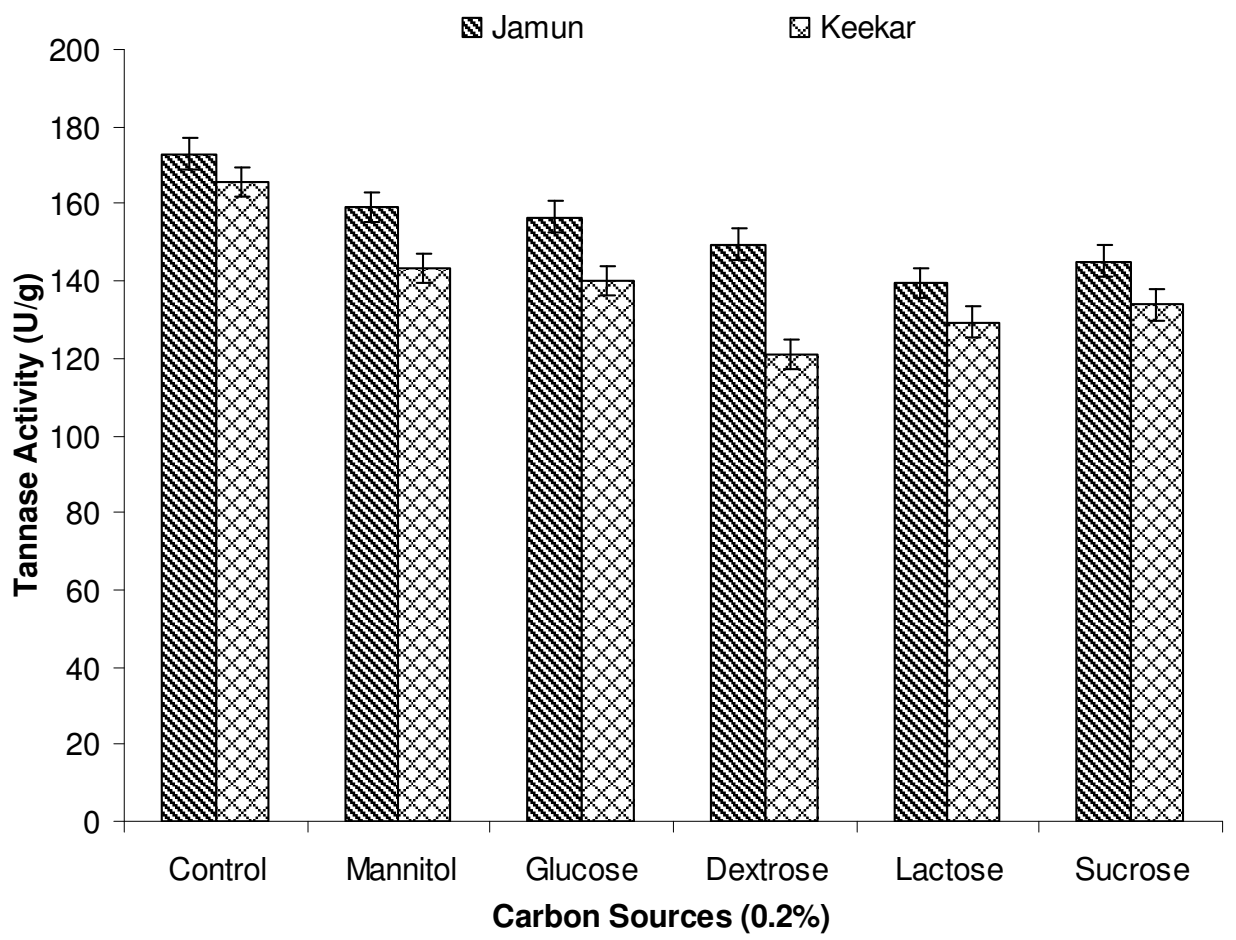

Figure 3. Effect of moisture level on tannase production by Penicillium atramentosum KM

(Growth conditions: $10 \mathrm{~g}$ jamun/keekar leaves as substrates ( $\mathrm{pH} 6.5$ ) incubated at $28^{\circ} \mathrm{C}$ for $72 \mathrm{~h}$.)

\section{Effect of nitrogen sources on tannase production}

Nitrogen source is very essential for growth and enzyme production by the microorganisms. The effect of different nitrogen sources $(0.2 \% \mathrm{w} / \mathrm{v})$ was evaluated. The results showed maximum tannase production with sodium nitrate supplemented in the moistening agent i.e. $167.45 \mathrm{U} / \mathrm{g}$ in case of jamun leaves and $163.47 \mathrm{U} / \mathrm{g}$ in case of keekar leaves (Fig. 5). But when the different concentrations of sodium nitrate were evaluated, it was found that $0.1 \%(\mathrm{w} / \mathrm{v})$ concentration of sodium nitrate showed maximum tannase production i.e. $169.92 \mathrm{U} / \mathrm{g}$ in case of jamun leaves, while $0.2 \%$ (w/v) concentration of sodium nitrate showed maximum tannase production i.e. 165.23 U/g in case of keekar leaves (Fig. 6). Different workers reported different inorganic nitrogen sources for optimum tannase production in fungi. Similar to our results, Hadi et al. (14) and Bradoo et al. (9) also observed maximum enzyme production with sodium nitrate by $R$. oryzae and with ammonium nitrate by $A$. japonicus, respectively. In our 
previous study (22), we reported maximum tannase production with ammonium sulphate by Aspergillus fumigatus MA. Banerjee and Pati (6) found maximum tannase production using Di-ammonium hydrogen phosphate. Kar et al. (16) reported optimal tannase production with the supplementation of ammonium chloride. However, a few workers reported inhibitory effects of nitrogen source on enzyme production. Sabu et al. (30) reported a decrease in tannase production in presence of nitrogen source by fungal culture in case of the medium using palm kernel cake (PKC) whereas there was an increase in the tannase activity in case of tamarind seed powder (TSP).

Under optimized conditions, we are able to get enzyme production of $170.75 \mathrm{U} / \mathrm{g}$ using jamun leaves and $165.56 \mathrm{U} / \mathrm{g}$ using keekar leaves. In our previous report (22), also we were able to produce almost same yield of tannase (174.32 U/g) from Aspergillus fumigatus MA under SSF using jamun leaves. The yield is much higher as compared to the other reported tannase producers under SSF. Banerjee et al. (5) reported the tannase activity of $2.93 \mathrm{U} / \mathrm{g}$ from Aspergillus acuelatus DBF9 using wheat bran. Pinto et al. (27) found that $67.5 \mathrm{U} / \mathrm{g}$ of tannase was produced from Aspergillus niger 11T25A5 under SSF. Sabu et al. $(30,31)$ reported an yield of $13.03 \mathrm{U} / \mathrm{g}$ using PKC and $6.44 \mathrm{U} / \mathrm{g}$ using TSP from Aspergillus niger ATCC 16620 and a yield of $0.85 \mathrm{U} / \mathrm{gds}$ from Lactobacillus sp. ASRS1 using TSP. Mukherjee and Banerjee, (25) observed that coculture of Rhizopus oryzae and Aspergillus foetidus produced tannase yield of $41.3 \mathrm{U} / \mathrm{ml}$ under modified SSF conditions. Rodrigues et al. (29) reported the tannase production of 2.40 $\mathrm{U} / \mathrm{g}$ using cashew apple baggase and $2.5 \%$ tannic acid from Aspergillus oryzae.

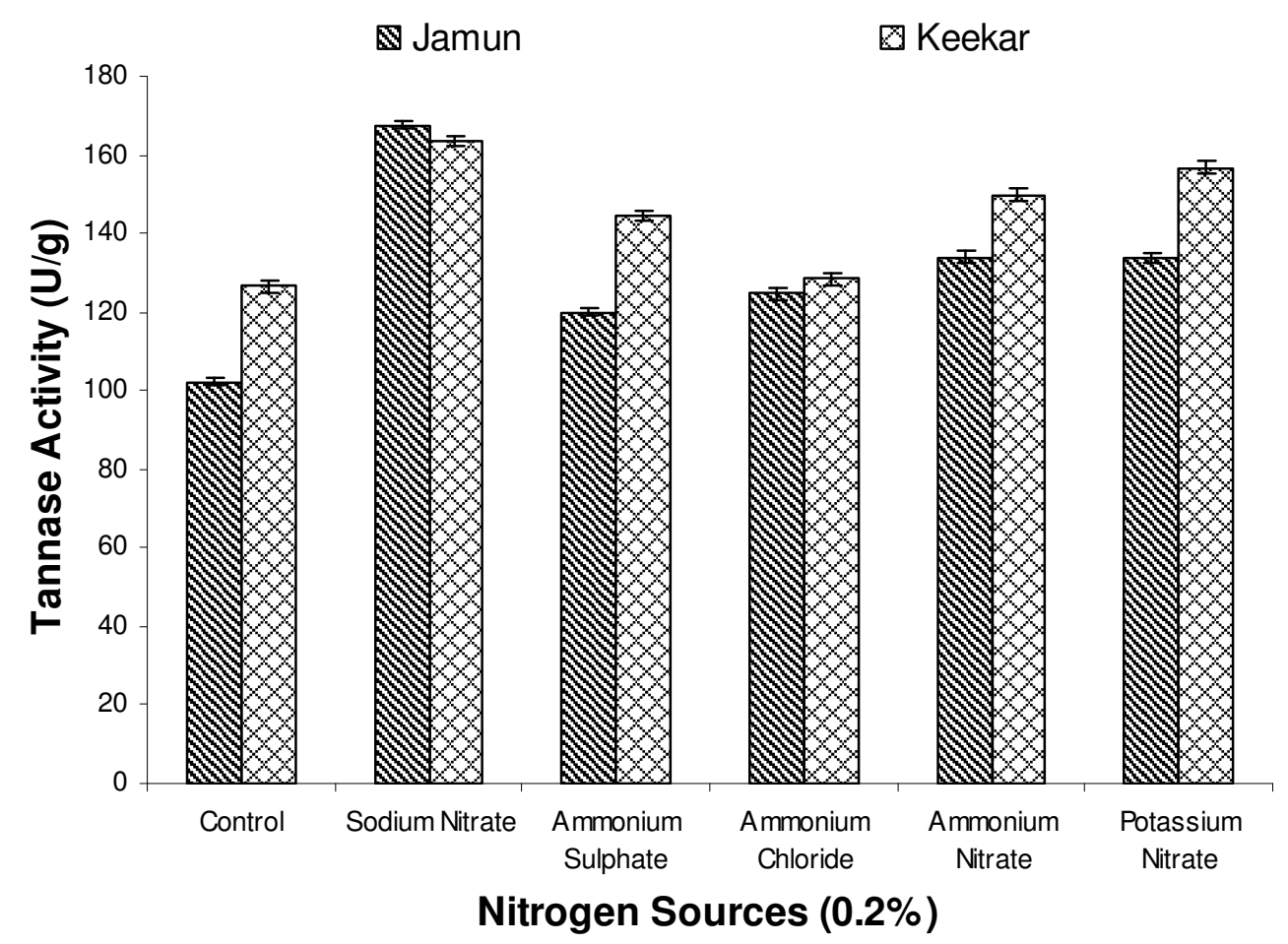

Figure 5. Effect of various nitrogen sources on tannase production by Penicillium atramentosum KM. (Growth conditions: $10 \mathrm{~g}$ jamun/keekar leaves as substrates (pH 6.5) incubated at $28^{\circ} \mathrm{C}$ for $96 \mathrm{~h}, 1: 2$ substrate: moisture agent.) 


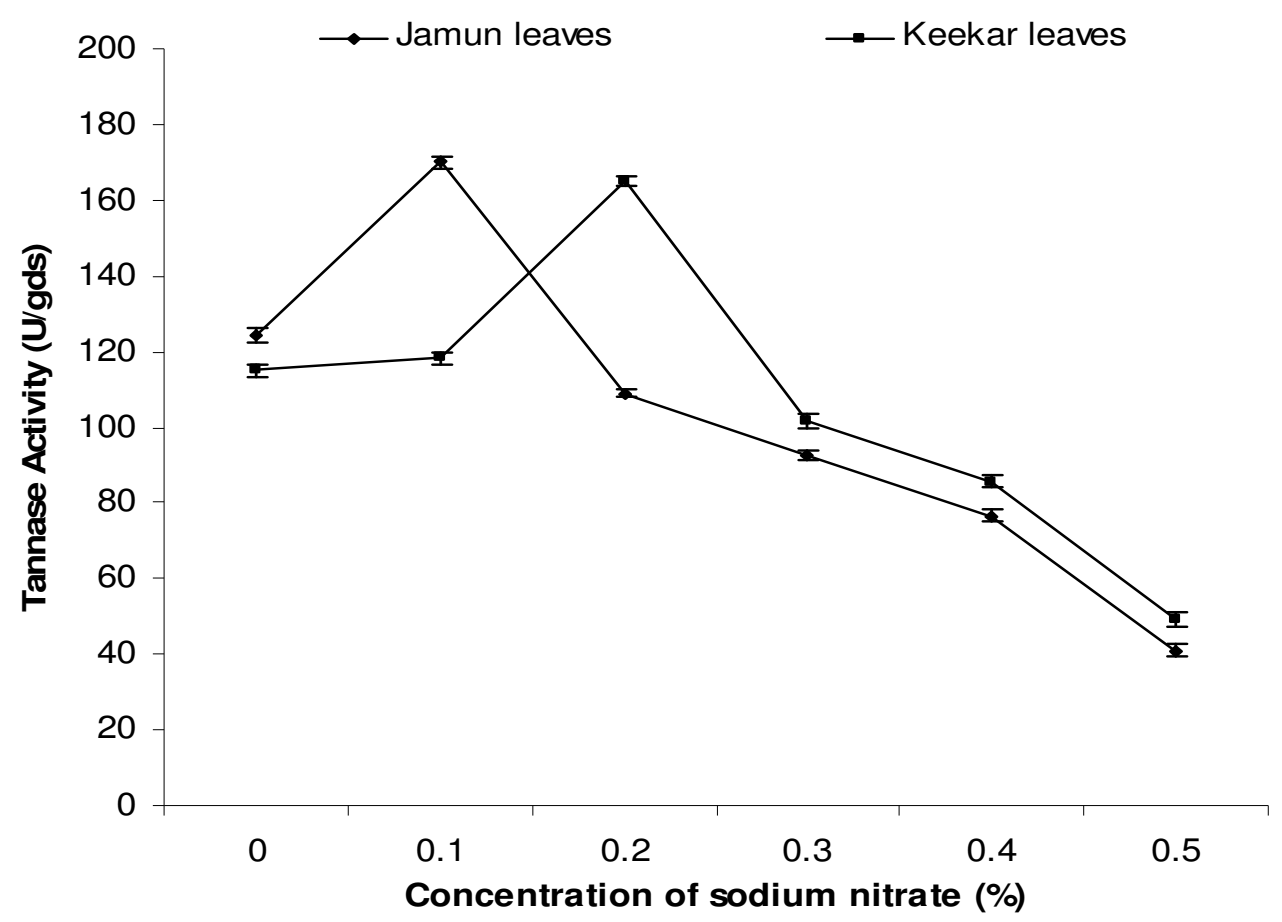

Figure 6. Effect of various concentrations of sodium nitrate on tannase production by Penicillium atramentosum KM. (Growth conditions: $10 \mathrm{~g}$ jamun/keekar leaves as substrates, $\mathrm{pH} 6.5,1: 2$ substrate: moisture agent, incubated at $28^{\circ} \mathrm{C}$ for $96 \mathrm{~h}$ )

\section{Application of tannase enzyme in wine clarification and solid tea cream solubilization}

The colloidal suspension of both the wine samples was treated with tannase at $35^{\circ} \mathrm{C}$ under stationary conditions for different time intervals. After $3 \mathrm{~h}$, the colloidal suspension became clear in both the cases. The tannin contents in control condition of jamun wine and grape wine was found to be $123.42 \mu \mathrm{g} / \mathrm{ml}$ and $98.39 \mu \mathrm{g} / \mathrm{ml}$ respectively. After $3 \mathrm{~h}$ tannase treatment of both the samples of the wine, the tannin content was decreased to $75.73 \mu \mathrm{g} / \mathrm{ml}$ and $55.51 \mu \mathrm{g} / \mathrm{ml}$. our enzyme resulted in $38 \%$ reduction of tannic acid content in case of jamun wine and $43.59 \%$ reduction of tannic acid content in case of grape wine (Fig.7). Similar to our work, Chae et al. (10) has explored the tannase enzyme treatment in the manufacturing of the acorn wine.

The tea extract was treated with the partially purified enzyme i.e. ammonium sulphate precipitated enzyme (60-80\%) at $35^{\circ} \mathrm{C}$ at different time intervals. The original tannic acid content in the tea extract (control) was found to be 203.7 $\mu \mathrm{g} / \mathrm{ml}$. After $3 \mathrm{~h}$ of the tannase treatment, tea cream was dissolved and the tannic acid content was found to be 49.03 $\mu \mathrm{g} / \mathrm{ml}$ (Fig. 5). The enzyme from $P$. atramentosum KM resulted in $74 \%$ of the tannin content reduction in the tea extract. This feature makes this enzyme a powerful tool in instant tea manufacturing at industrial level. The most important requisite of instant tea is cold water solubility (12). The tea cream is a cold water insoluble precipitate which occurs naturally in brewed tea beverages when allowed to stand for hours at $4^{\circ} \mathrm{C}$. It is therefore a major problem in instant tea manufacturing (32). Similar to our work, Tokino (34) also reported the solubilization of cold water insoluble portion of extracted tea solids by the use of tannase enzyme. Lee et al. (21) reported the use of cellulose and protease to increase the yield of soluble solids obtained from tea leaves for preparing 
instant tea. Agbo et al. (1) also reported the use of glucose oxidase and tannase to produce the tea extract which forms little or no haze when stored at refrigeration temperature. The tea cream is usually discarded which leads to a considerable loss of the major flavor compounds. The chemical method of tea solubilization leads to unpleasant coloration (12).

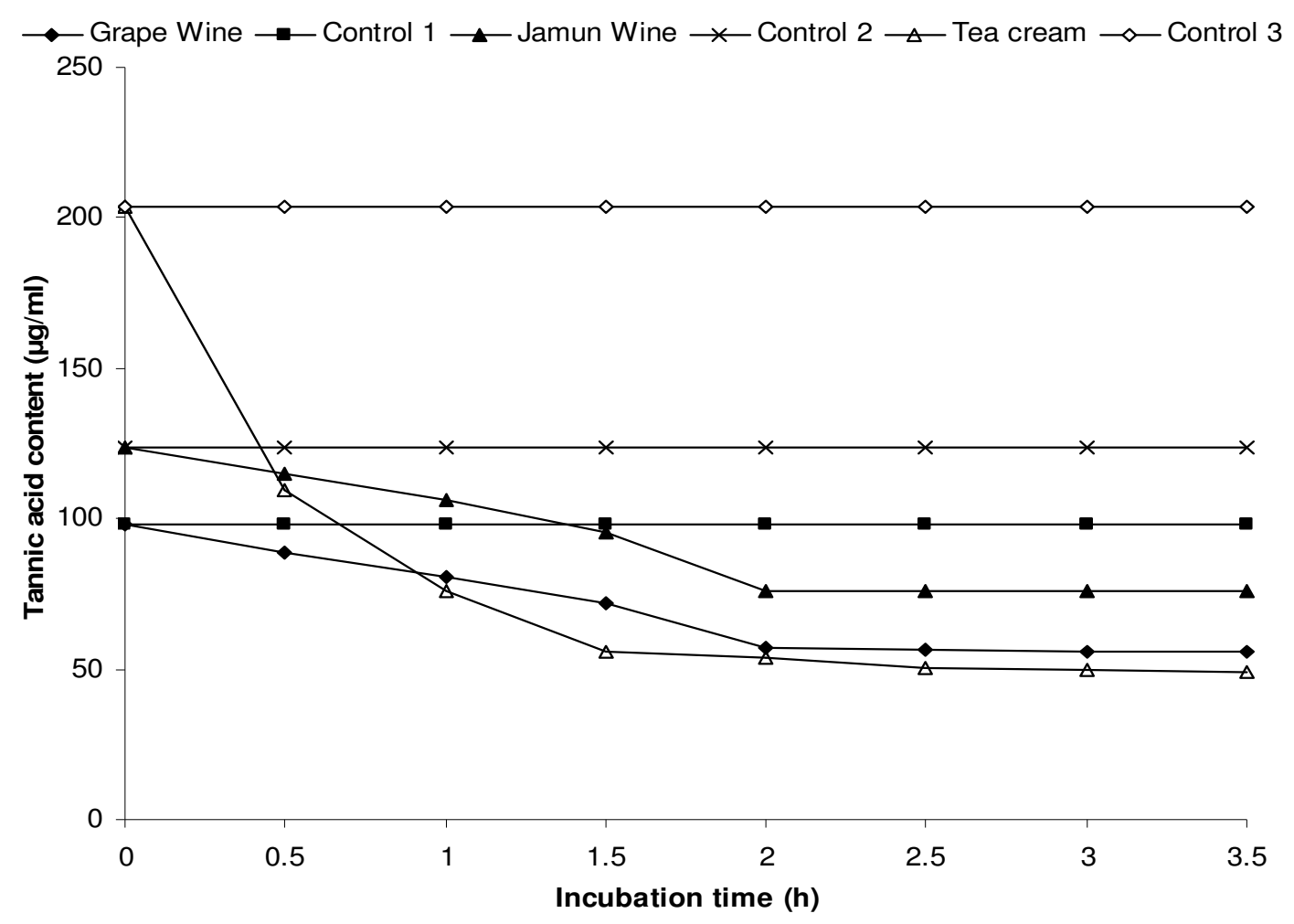

Figure 7. Application of tannase produced by Penicillium atramentosum in wine clarification and solid tea cream solubilization.

\section{CONCLUSION}

The present investigation suggests that agro residues such as jamun and keekar leaves can be one of the best and costeffective alternatives to the costly pure tannic acid for industrial production of microbial tannase. The fungal enzyme has interesting characteristics and this fact encourages further studies, including its production at industrial scale.

\section{ACKNOWLEDGMENT}

We are thankful to Prof. Ashok Aggarwal from Department of Botany, Kurukshetra University, Kurukshetra for the identification of the culture. The senior research fellowship under Rajiv Gandhi National Fellowship scheme (University Grant Commission) sponsored by the Ministry of Social Justice \& Empowerment and Ministry of Tribal Affairs, Govt. of India to the first author is gratefully acknowledged.

\section{REFERENCES}

1. Agbo, F.; Spradlin, J.E. (1995). Enzymatic clarification of tea extracts. Patent 5, 445,836.

2. Aguilar, C.N.; Augur, C.; Favela-Torre, E.; Viniega-Gonzalez, G. (2001). Induction and repression patterns of fungal tannase in solid-state and submerged cultures. Proc. Biochem. 36, 565-570. 
3. Aguilar, C.N.; Rodríguez, R.; Gutiérrez-Sánchez, G.; Augur, C.; FavelaTorres, E.; Prado-Barragan, L.A.; Ramírez- Coronel A.; ContrerasEsquivel, J.C. (2007). Microbial tannases: advances and perspective. Appl. Microbiol. Biotechnol. 76 (1), 47-59.

4. Anwar, Y.A.S.; Hasim, Artika, I.M. (2007). The Production of Tannin Acyl Hydrolase from Aspergillus niger. Microbiol. Indonesia. 1 (2), 9194.

5. Banerjee, D.; Mondal, K.C.; Pati, B.R. (2007). Tannase production by Aspergillus aculeatus DBF9 through solid state fermentation. Acta Microbiologica et Immunologica Hungarica. 54 (2), 159-166.

6. Banerjee, D.; Pati, B.R. (2007). Optimization of tannase production by Aureobasidium pullulans DBS 66. J. Microbiol. Biotechnol. 17 (6), 1049-1053.

7. Barthomeuf, C.; Regerat, F.; Pourrat, H. (1994). Production, purification and characterization of a tannase from Aspergillus niger LCF 8. J. Ferment. Bioeng. 77, 320-323.

8. Batra, A.; Saxena, R.K. (2005). Potential tannase producers from the genera Aspergillus and Penicillium. Proc. Biochem. 40, 1553-1557.

9. Bradoo, S.; Gupta, R.; Saxena, R.K., (1997). Parametric optimization and biochemical regulation of extracellular tannase from Aspergillus japonicus. Proc. Biochem. 32 (2), 135-139.

10. Chae, S.K.; Yu, T.J. (1983). Experimental manufacture of Acron wine by fungal tannase. Hanguk. Sipkum. Kwahakhoechi. 15, 326-332.

11. Chatterjee, R.; Dutta, A.; Banerjee, R.; Bhattacharyya, B.C. (1996). Production of tannase by solid-state fermentation. Bioproc. Biosyst. Eng. 14 (3), 159-162.

12. Coggon, P.; Graham, H.N.; Sanderson, G.W. (1975). Cold water soluble tea. BP 1,380. 135.

13. Das Mohapatra, P.K.; Mondal, K.C.; Pati, B.R. (2006). Production of tannase through submerged fermentation of tannin-containing plant extracts by Bacillus licheniformis KBR6. Pol. J. Microbiol. 55 (4), 297301.

14. Hadi, T. A.; Banerjee, R.; Bhattacharyya, B. C. (1994). Optimization of tannase synthesis by newly isolated Rhizopus oryzae. Bioproc. Engg. 11, 239- 243.

15. Haggerman, A. E.; Butler, L.G. (1978). Protein precipitation method for determination of tannins. J. Agric. Food Chem. 26, 809-812.

16. Kar, B.; Banerjee, R.; Bhattacharyya, B.C. (2003). Effect of additives on the behavioural properties of tannin acyl hydrolase. Proc. Biochem. 38 (9), 1395-1401.

17. Kasieczka, B.M.; Kuk, K.; Kalinowska, K. (2007). Purification and characterization of two cold-adapted extracellular tannin acyl hydrolases from an Antarctic strain Verticillium sp. P9. Appl. Microbiol. Biotechnol. 77 (1), 77-89.

18. Kumar, R.A.; Gunasekaran, P.; Lakshmanan, M. (1999). Biodegradation of tannic acid by Citrobacter freundii isolated from a tannery effluent. $J$.
Basic Microbiol. 39 (3), 161-168.

19. Lekha, P.K.; Lonsane, B.K. (1997). Production and application of tannin acyl hydrolase: state of art. Adv. Appl. Microbiol. 44, 215-260.

20. Liu, R.T.; Proudley, J.C.; Delaware. (1992).Treatment of black tea. $5,130,154$

21. Lee, E.C. (1993). Water soluble tea extracts. 5, 196, 214.

22. Manjit, Yadav, A.; Aggarwal, N.K.; Kumar, K.; Kumar, A. (2008). Tannase production by Aspergillus fumigatus MA under solid-state fermentation. World J. Microbiol. Biotechnol. 24, 3023-3030.

23. Mondal, K.C.; Pati, B.R. (2000). Studies on the extracellular tannase from newly isolated Bacillus licheniformis KBR 6. J. Basic Microbiol. 40, 223-232.

24. Mondal, K.C.; Banerjee, D.; Jana, M.; Pati, B.R. (2001). Colorimetric assay for determination of Tannin Acyl Hydrolase (E.C. 3.1.1.20) activity. Anal. Biochem. 295, 168-171.

25. Mukherjee, G.; Banerjee, R. (2006). Effects of temperature, pH and additives on the activity of tannase produced by a co-culture of Rhizopus oryzae and Aspergillus foetidus. World J. Microbiol. Biotechnol. 22, 207212.

26. Oliveri, C.; Campisano, A.; Catara, A.; Cirvilleri, G. (2007). Characterization and faflp genotyping of penicillium strains from postharvest samples and packinghouse environments. J. Plant Pathol. 89 (1), 29-40.

27. Pinto, G.A.S.; Leite, S.G.F.; Terzi, S.C.; Couri, S. (2001). Selection of tannase-producing aspergillus niger strains. Braz. J. Microbiol. 32, 2426.

28. Rajakumar, G.S.; Nandy, S.C. (1983). Isolation, Purification, and Some Properties of Penicillium chrysogenum tannase. Appl. Environ. Microbiol. 46, 525-527.

29. Rodrigues, T.H.S.; Dantas, M.A.A.; Pinto, G.A.S.; Goncalves, L.R.B. (2007). Tannase Production by Solid State Fermentation of Cashew Apple. Bagasse. Appl. Biochem. Biotechnol. 136-140.

30. Sabu, A.; Pandey, A.; Daud, M.J.; Szakacs, G. (2005). Tamarind seed powder and palm kernel cake: two novel agro residues for the production of tannase under solid state fermentation by Aspergillus niger ATCC 16620. Biores. Technol. 96 (11), 1223-1228.

31. Sabu, A.; Augur, C.; Swati, C.; Pandey, A. (2006). Tannase production by Lactobacillus sp. ASR-S1 under solid-state fermentation. Proc. Biochem. 41, 575-580.

32. Sanderson, G.W.; Englewood, N.J.; Coggon, P.; Orangeburg, N.Y. (1974). Green tea conversion using tannase and natural tea leaves. U. S. Pat. 3,812,266.

33. Treviño-Cueto B.; Luis, M.; Contreras-Esquivel, J.C.; Rodríguez, R.; Aguilera, A.; Aguilar, C.N. (2007). Gallic acid and tannase accumulation during fungal solid state culture of a tannin-rich desert plant (Larrea tridentata Cov.) Biores. Technol. 98, 721-724. 
34. Takino, Y. (1976). Enzymatic solubilization of tea cream. 3,959,497. Van de Lagemaat, J.; Pyle, D.L. (2005). Modeling the uptake and growth kinetics of Penicillium glabrum in a tannic acid-containing solid-state fermentation for tannase production. Proc. Biochem. 40 (5), 1773-82.
35. Van de Lagemaat, J.; Pyle, D.L. (2005). Modeling the uptake and growth kinetics of Penicillium glabrum in a tannic acid-containing solid-state fermentation for tannase production. Proc. Biochem. 40 (5), 1773-82. 